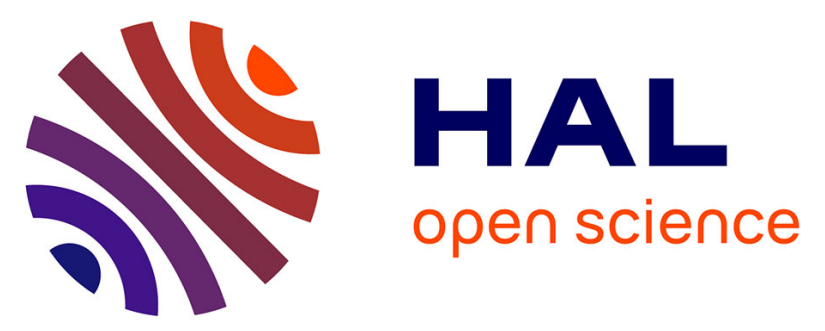

\title{
Occurrence of the Fusarium T-2- and HT-2-toxins in oats from cultivar studies in Germany and degradation of the toxins during grain cleaning treatment and food processing
}

Christine Schwake-Anduschus, Georg Langenkämper, Guenter Unbehend, Richard Diedrich, Erwin Märtlbauer, Klaus Münzing

\section{To cite this version:}

Christine Schwake-Anduschus, Georg Langenkämper, Guenter Unbehend, Richard Diedrich, Erwin Märtlbauer, et al.. Occurrence of the Fusarium T-2- and HT-2-toxins in oats from cultivar studies in Germany and degradation of the toxins during grain cleaning treatment and food processing. Food Additives and Contaminants, 2010, 27 (09), pp.1253-1260. 10.1080/19440049.2010.487499 . hal00600443

\section{HAL Id: hal-00600443 https://hal.science/hal-00600443}

Submitted on 15 Jun 2011

HAL is a multi-disciplinary open access archive for the deposit and dissemination of scientific research documents, whether they are published or not. The documents may come from teaching and research institutions in France or abroad, or from public or private research centers.
L'archive ouverte pluridisciplinaire HAL, est destinée au dépôt et à la diffusion de documents scientifiques de niveau recherche, publiés ou non, émanant des établissements d'enseignement et de recherche français ou étrangers, des laboratoires publics ou privés. 


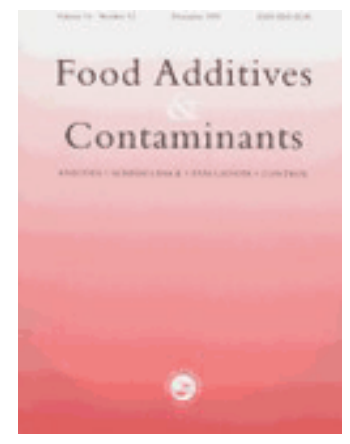

\section{Occurrence of the Fusarium T-2- and HT-2-toxins in oats from cultivar studies in Germany and degradation of the toxins during grain cleaning treatment and food processing}

\begin{tabular}{|r|l|}
\hline Journal: & Food Additives and Contaminants \\
\hline Manuscript ID: & TFAC-2009-360.R1 \\
\hline Manuscript Type: & Original Research Paper \\
\hline Author: & 13-Apr-2010 \\
\hline Complete List of Authors: & $\begin{array}{l}\text { Schwake-Anduschus, Christine; Max Rubner-Institut, Department of } \\
\text { Safety and Quality of Creals } \\
\text { Langenkämper, Georg; Max Rubner-Institut, Department of Safety } \\
\text { and Quality of Cereals } \\
\text { Unbehend, Guenter; Max Rubner-Institut, Department of Safety } \\
\text { and Quality of Cereals } \\
\text { Diedrich, Richard; Ludwig-Maximilians-Universität, Department of } \\
\text { Veterinary Sciences } \\
\text { Märtlbauer, Erwin; Ludwig-Maximilians-Universität, Department of } \\
\text { Veterinary Sciences } \\
\text { Münzing, Klaus; Max Rubner-Institut, Department of Safety and } \\
\text { Quality of Cereals }\end{array}$ \\
\hline Methods/Techniques: & $\begin{array}{l}\text { Chromatography - HPLC, LC/MS, Screening - ELISA, } \\
\text { Chromatographic analysis }\end{array}$ \\
\hline Additives/Contaminants: & $\begin{array}{l}\text { Mycotoxins, Mycotoxins - trichothecenes, Mycotoxins - fusarium, } \\
\text { Residues }\end{array}$ \\
\hline Food Types: & Bread, Cereals and grain, Cereals, Baby food \\
\hline & \\
\hline
\end{tabular}

\section{SCHOLARONE \\ Manuscripts}




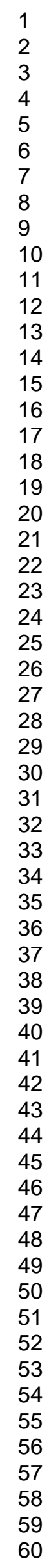

2

4

5

7

8

10

11

12

14

15

16

17

19

20

21

23

24

26

27

29

30

32

33

34

35

37

38

41

42

43

44

45

46

47

48

49

51

52

53

54

55

57

58

59

60

http://mc.manuscriptcentral.com/tfac Email: fac@tandf.co.uk 


\title{
Occurrence of the Fusarium T-2- and HT-2-toxins in oats from cultivar studies in Germany and degradation of the toxins during grain cleaning treatment and food processing*
}

\author{
C. Schwake-Anduschus ${ }^{*}{ }^{\mathrm{a}}$, G. Langenkämper ${ }^{\mathrm{a}}$, G. Unbehend ${ }^{\mathrm{a}}$, R. Dietrich $^{\mathrm{b}}$, E. Märtlbauer $^{\mathrm{b}}$, \\ K. Münzing ${ }^{\mathrm{a}}$
}

${ }^{a}$ Department of Safety and Quality of Cereals, Max Rubner-Institut (MRI), Federal Research Institute of Nutrition and Food, Schützenberg 12, 32756 Detmold, Germany.

${ }^{b}$ Department of Veterinary Sciences, Faculty of Veterinary Medicine, Ludwig-MaximiliansUniversität München, Schönleutner Str. 8, 85764 Oberschleissheim, Germany.

\begin{abstract}
Corresponding author. Email: christine.schwake-anduschus@mri.bund.de; ${ }^{\square}$ authors contributed equally.

* Presented at ISM Conference 2009 held in Tulln (Austria) from 9-11 Sept. 2009.
\end{abstract}

\begin{abstract}
For the Fusarium trichothecene mycotoxins T-2 and HT-2 a combined (T-2+HT-2) temporary Tolerable Daily Intake (tTDI) of $0.06 \mu \mathrm{g} \mathrm{kg}^{-1}$ body weight per day has been proposed at European level in 2001 (Opinion of the Scientific Committee on Food). In the near future, maximum levels for these trichothecenes will be regulated by the European Commission as announced in EU (VO) 1881/2006. For the implementation of these maximum levels more data on occurrence and behaviour of T-2- and HT-2-toxins in primary agricultural products as well as during cleaning treatment and food processing are needed. In the current work we determined the T-2/HT-2 concentrations in four oat cultivars (Aragon, Dominik, Ivory, Pergamon) from 10 different agricultural sites in Germany, grown in cultivar studies in 2007. The grains were de-hulled, oat meal was prepared and bread with $20 \%$ oat meal and $80 \%$ wheat flour was baked. In the cereal processing chain, samples were taken at various steps and subsequently analysed for their T2/HT-2 content. We employed LC-MS and an immunological screening method (ELISA) for T-
\end{abstract}




\section{Introduction}

Fusarium spp. are phytopathogenic fungi infecting a large number of plant species. Depending on the Fusarium species, colonisation of the host plant is often accompanied by production of various mycotoxins, including trichothecenes, which are of concern with respect to food and feed safety (Kimura et al. 2007). According to their chemical structure, trichothecenes are categorised into four different types, where type A and B trichothecenes often occur in Fusarium infected cereals (Foroud and Eudes 2009). The type B trichothecene deoxynivalenol (DON) is regarded the most frequently detected mycotoxin worldwide in cereals and cereal products. Depending on cereal species, production stage and intended use of the foodstuff, the European Union (EU) has set legal limits for DON varying between 200 and $1,750 \mu \mathrm{g} \mathrm{kg}^{-1}$ (European Commission 2006). The EU has called for more data concerning the occurrence, behaviour and toxicity of T-2- and HT-2-toxins and legal limits for these toxins had been envisaged to be set by July 2008 (European Commission 2006). However, these limits have presently not been established.

Toxicity levels of T-2-toxin are approximately 10 times higher than those of DON (Ueno 1983). Accordingly, a relatively low temporary Tolerable Daily Intake (tTDI) for the sum of T-2 and HT-2 of $0.06 \mu \mathrm{g} \mathrm{kg}^{-1}$ body weight has been proposed by the Scientific Committee of Food (European Commission 2001). It has been found that in oats frequency of occurrence 
and levels of T-2- and HT-2-toxins are considerably higher than e. g. in wheat, rye and soy bean. However, in 2001 the data base was regarded as being too small to assess, if daily uptake of the toxins with food was on average below the tTDI (JECFA 2001). In recent years several authors have studied the occurrence of T-2- and HT-2-toxins in diverse cereals and cereal products, e.g. in conventional and organic bread (Schollenberger et al. 2005), in diverse grains and feedstuff (Schollenberger et al. 2006), in conventionally and organically grown oats (Gottschalk et al. 2007; Edwards 2009b) and in barley (Edwards 2009a). It was also assessed, whether toxin levels were reduced during processing of oats (e.g. de-hulling) and malting and brewing of barley (Edwards et al. 2009). In Germany, there has been performed a relatively large survey of various types of foods for levels of T-2- and HT-2-toxins (Curtui et al. 2009). The outcome of the latter survey was that toxins were found at low concentrations in a large percentage of cereal based products, where highest frequency of occurrence and highest median values for T-2- and HT-2-toxins were obtained in oat based products. The relatively low concentrations of the toxins lead the authors to conclude that for the average consumers health risks would not be expected. On the other hand, it cannot be ruled out that high intake consumers, especially children, are at a health risk due to elevated levels of T-2and HT-2-toxins in oat based products. For this reason the current work examines two aspects concerning levels of T-2 and HT-2 toxins in oats $i$ ) influence of different cultivars and different growing areas within Germany and ii) influence of a range of processing steps during the production of oat foodstuffs.

\section{Material and methods}

\section{Sample collection, preparation and further treatment}

The oat samples from cultivar studies in 2007 were provided from the German Federal Plant Variety Office (BSA) in Hannover, Germany. The four oat cultivars Aragon, Dominik, Ivory and Pergamon were grown on ten different sites, distributed relatively evenly in Germany. On every site, plants were treated analogous to normal agricultural practise with several applications of fungicides. Plant treatments between sites were not uniform and differed due to local conditions such as infection status and weather patterns (2010 personal communication D. Rentel, BSA, unreferenced, see 'Acknowledgements'). At least $2 \mathrm{~kg}$ of the harvested raw material was stored at room temperature in the dark until grinding an aliquot of $300 \mathrm{~g}$ per sample in a mill with $500 \mu \mathrm{m}$ sieve pore size (Retsch, Haan, Germany). The ground raw oat samples $(\mathrm{n}=40)$ were screened using direct competitive enzyme-linked immunosorbent assays (ELISA) for simultaneous detection of T-2/HT-2-toxins according to 
Hocke (2008). Out of these samples, we chose eight samples with levels higher than $100 \mu \mathrm{g}$ $\mathrm{kg}^{-1} \mathrm{~T}-2 / \mathrm{HT}-2$ for the further experiments.

Approximately $1 \mathrm{~kg}$ each of the eight chosen raw oats samples were cleaned using a laboratory scale grain cleaner (Labofix, Schmidt-Seeger, Beilngries, Germany), which separates foreign material from the oat grains. Half of the cleaned oats were de-hulled with an impact de-huller operating with compressed air (Figure 1). Approximately $0.5 \mathrm{~kg}$ of each, cleaned and de-hulled oats, were ground separately as described above. The ground samples were stored in glass bottles at room temperature in the dark until analysis and further usage for processing experiments.

For determination of T-2-/HT-2-toxin levels in the eight raw oats samples, the cleaned and de-hulled oat samples as well as in the processed material we employed an LC-MS method.

\section{Preparing "porridge” from oat meal}

"Porridge" was prepared by adding $20 \mathrm{~g}$ whole oat meal, obtained from cleaned oats, to $100 \mathrm{~mL}$ tap water. The mixture was stirred thoroughly and the porridge was heated $\left(30{ }^{\circ} \mathrm{C}\right.$ to $96{ }^{\circ} \mathrm{C}$ in $22 \mathrm{~min}, 1 \mathrm{~min}$ at $96^{\circ} \mathrm{C}$ ) in a Micro Visco-Amylo-Graph ${ }^{\circledR}$ MVAG (Brabender, Duisburg, Germany), which ensures good mixing of the sample without sedimentation of particles and steam loss. The preparations were done with a controlled temperature cycle of heating and holding, using fixed shear conditions. This ensures highly reproducible gelatinization and pasting profiles of the oat porridge. After this a freeze-drying procedure of the porridge followed. The porridge preparation from each sample was performed in three replicates, all of which were subsequently analysed for T2- and HT-2-toxins with LC-MS.

\section{Bread manufacturing}

In order to obtain bread contaminated with T-2- and HT-2-toxins, wheat flour and whole oat meal (obtained from cleaned oats) with known levels of T-2- and HT-2-toxins was used. The bread recipe contained a mixture of $80 \%$ wheat flour and $20 \%$ whole oat meal. The wheat flour quality (type 550) was characterised using various ICC-Standard methods. The flour had 14\% water content (ICC 110/1), 385 s falling number (ICC 107/1), 11.6\% protein content (ICC 105/1), 27.4\% gluten content (ICC 137/1), $36 \mathrm{~mL}$ sedimentation value (ICC 116/1), $57.8 \%$ water absorption (ICC 115/1) and 0.59\% ash content (ICC 104/1). Descriptions of the ICC methods are available in the internet at http://www.icc.or.at/methods3.php. 
The bread dough was mixed using $800 \mathrm{~g}$ wheat flour, $200 \mathrm{~g}$ whole oat meal, $50 \mathrm{~g}$ fresh baker's yeast, $15 \mathrm{~g}$ pure peanut oil (partly hydrogenated), $15 \mathrm{~g}$ white refined sugar, $20 \mathrm{~g}$ table salt and $580 \mathrm{~g}$ water. Manufacturing conditions were in principle identical with industrial bread making processes. Details of the conditions are listed in Table 1. For each sample bread manufacturing was replicated three times.

\section{Bread and porridge sample preparation}

Bread samples were ripped into small pieces and air dried for two days at room temperature. Dried bread and freeze-dried porridge samples were ground in a mill (500 $\mu \mathrm{m}$ sieve pore size, Retsch, Haan, Germany). Ground material was stored in glass bottles in the dark. Water content of all materials were analysed with a moisture analyzer (Sartorius AG, Göttingen, Germany).

\section{Chemicals}

Methanol (LC-MS grade) was purchased from Roth (Karlsruhe, Germany) and acetonitrile (HPLC grade) was obtained from Baker (Deventer, The Netherlands). Formic acid p.a. was from Merck (Darmstadt, Germany) and the standard solutions of T-2- and HT-2-toxin, both in acetonitrile, were purchased from Biopure (Tulln, Austria).

\section{Analytical methods}

\section{Enzyme-linked immunosorbent assay (ELISA)}

Briefly, ground oat material (5 g per extraction) was extracted with $70 \%$ methanol in water $(\mathrm{v} / \mathrm{v})$. After centrifugation the supernatant was cleaned by liquid-liquid extraction with ethyl acetate. Extracts were assayed in quadruplicate for concentration of T-2- and HT-2-toxins using microtitre plates. The limit of quantification for T-2- and HT-2-toxins was $0.5 \mu \mathrm{g} \mathrm{kg}^{-1}$ and recoveries were greater than $80 \%$. In interlaboratory studies a good reproducibility of the method was obtained: in 11 samples the $\mathrm{RSD}_{\mathrm{R}}$ values were between $9 \%$ and $31 \%$ and the mean $\operatorname{RSD}_{R}$ was $17 \%$ (Hocke 2008). Using the described ELISA method and a GC based method for detection of T-2- and HT-2-toxins on identical samples, there was a high correlation in the results $\left(\mathrm{r}^{2}=0.96\right)$, (Majerus et al. 2008).

\section{Liquid Chromatography Mass Spectrometry (LC-MS) -method}

Pressurized liquid extraction (PLE) and extract treatment. Ground material (10 g) was mixed with $4 \mathrm{~g}$ diatomaceous earth (Varian, Darmstadt, Germany) for keeping the sample porous. This mixture was placed on top of a layer of $2 \mathrm{~g}$ activated charcoal (Merck) in a $33 \mathrm{~mL}$ 
stainless steel cell (Dionex, Idstein, Germany). Extraction was done using an Accelerated Solvent Extractor (ASE 300) instrument (Dionex) with 20\% water in acetonitrile (v/v) as solvent under the following conditions: preheat $5 \mathrm{~min}$, static $5 \mathrm{~min}$, flush $130 \%$, purge $80 \mathrm{~s}$, cycles 5, pressure $15000 \mathrm{kPa}$, temperature $85^{\circ} \mathrm{C}$. The extract volume was adjusted to $100 \mathrm{~mL}$ with $20 \%$ water in acetonitrile (v/v) in a volumetric flask. A $10 \mathrm{~mL}$ aliquot of the extract was evaporated to dryness and subsequently redissolved in $0.3 \mathrm{~mL}$ methanol and $1.2 \mathrm{~mL}$ Milli$\mathrm{Q}^{\circledR}$-water (Millipore, Schwalbach, Germany). After filtration through a $0.2 \mu \mathrm{m}$ disposable syringe filter (Macherey-Nagel, Düren, Germany) extracts were transferred to vials and stored if necessary at minus $20^{\circ} \mathrm{C}$ prior to analysis.

Liquid Chromatography-System. Separations were performed using a LC- prominence system (Shimadzu, Duisburg, Germany) equipped with a Luna® phenyl-hexyl-column (150 x $2.0 \mathrm{~mm}$ I.D. particle size $5 \mu \mathrm{m}$ ) and a security guard (Phenomenex, Eschborn, Germany) at $40{ }^{\circ} \mathrm{C}$. The flow rate was $0.4 \mathrm{~mL}$ per minute and a gradient was mixed using Milli- $\mathrm{Q}^{\circledR}$-water with $1 \%(\mathrm{v} / \mathrm{v})$ formic acid as solvent $\mathrm{A}$ and methanol as solvent $\mathrm{B}$ applying the following gradient programme: start $10 \%$ solvent B, $10-40 \%$ solvent B (1 min), $40 \%$ solvent B (3 min), $40-80 \%$ solvent B (6 min), $80 \%$ solvent B $(4 \mathrm{~min}), 80-10 \%$ solvent B $(0.5 \mathrm{~min}), 10 \%$ solvent B (2.5 min).

Mass spectrometry. The linear ion trap triple quadrupole mass spectrometer (4000QTrap, Applied Biosystems, Darmstadt, Germany) with a TurboV ${ }^{\circledR}$-Source was operated in ESI(+) multi reaction mode (MRM, Table 2) with the following general settings: Curtain gas 28 psi, CAD gas medium, IS $5500 \mathrm{~V}$, temperature $315^{\circ} \mathrm{C}$, Gas $150 \mathrm{psi}$, Gas2 75 psi.

Quantification was carried out with a matrix matched calibration curve. For this purpose matrix standards were prepared by extracting a blank sample (each for raw oats, cleaned oats bread and porridge respectively) like any other sample until evaporation to dryness (see step PLE). Dried samples were dissolved in $1.2 \mathrm{~mL}$ water and $0.3 \mathrm{~mL}$ standard T-2-/HT-2 solution in methanol. Calibration-matrix-standards had concentrations between $110^{-6}$ and $710^{-4} \mathrm{~g} \mathrm{~L}^{-1}$ T-2- and HT-2-toxin in 20\% methanol/water (v/v), respectively. Detection limits (Signal to noise ratio $\geq 3$ ) were between $1 \mu \mathrm{g} \mathrm{kg}^{-1}$ and $3 \mu \mathrm{g} \mathrm{kg}^{-1}$ for $\mathrm{T}$-2-toxin and between $3 \mu \mathrm{g} \mathrm{kg}^{-1}$ and $5 \mu \mathrm{g} \mathrm{kg}^{-1}$ for HT-2-toxin, depending on the matrix.

Matrix effects and recovery. To determine the matrix effects the response factors (RF) of the peak areas were calculated as a function of the analyte concentration added with the matrix matched calibration standards. The results for the RFs of T-2 and HT-2 in raw oats, porridge and bread are shown in Figure 2. The response factors within a specific matrix were very constant down to a concentration of $30 \mu \mathrm{g} \mathrm{kg}^{-1}$. At toxin concentrations lower $30 \mu \mathrm{g} \mathrm{kg}^{-1}$ 
RFs became more variable. Concentration dependent RFs of T-2- and HT-2-toxins were different in raw oats, bread and porridge samples, respectively. RFs were lowest and little variable for the heated and highly stirred porridge samples, indicating a high, but homogeneous content of interfering organic matrix. The RF values for bread samples were generally factor four higher then in porridge. In bread RF values were very even between 30 and $600 \mu \mathrm{g} \mathrm{kg}^{-1}$ T2-/HT-2-toxins and increased steadily, when toxin concentrations were lower $30 \mu \mathrm{g} \mathrm{kg}^{-1}$. The raw oat samples exhibited highest and slightly more variable RFs. For both, T2-toxin and HT-2-toxin a similar dependency of the RFs from the sample matrix was found.

In order to assess recovery of the toxins in the assay system, spiking experiments were done by adding 1,2 or $5 \mu \mathrm{g}$ T-2 and HT-2 to $10 \mathrm{~g}$ of a blank sample in three replications. After an incubation time of two hours, the samples were processed as described previously. Recovery data for T-2-toxin were $72 \%$ in cleaned oats, $88 \%$ in bread and $93 \%$ in porridge, respectively. For the HT-2-toxin we obtained $100 \%$ recovery in cleaned oats, $85 \%$ in bread and $102 \%$ in porridge.

\section{Results and discussion}

On ten different agricultural sites, distributed relatively evenly in Germany the four oat cultivars Aragon, Dominik, Ivory and Pergamon had in sum T-2/HT-2 levels ranging from 9 to $623 \mu \mathrm{g} \mathrm{kg}^{-1}$, as determined with ELISA (Table 3). Over all cultivars and all growing sites the median was $48 \mu \mathrm{g} \mathrm{kg}^{-1}$, the mean was $102 \mu \mathrm{g} \mathrm{kg}^{-1}$ and the $90^{\text {th }}$ percentile was $191 \mu \mathrm{g} \mathrm{kg}^{-1}$ T-2-/HT-2-toxin. In comparison, oats from various regions in the UK showed nearly five times higher values, i. e. for these oats the median and the mean values of the sum of T-2- and

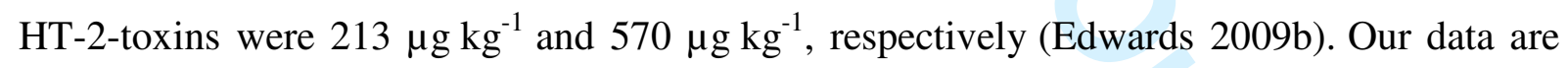
more in accordance with results obtained for oats sampled in Germany: e.g. oats from southwest Germany $(n=17)$, collected in the years 2000 and 2001. They had maximum levels of approximately $800 \mu \mathrm{g} \mathrm{kg}^{-1}$ with a mean of $255 \mu \mathrm{g} \mathrm{kg}^{-1} \mathrm{~T}-2 / \mathrm{HT}-2$ (Schollenberger et al. 2006). Similarly, oats including hulls $(\mathrm{n}=19)$ and de-hulled oats $(\mathrm{n}=21)$ contained in the mean 118 and $6.9 \mu \mathrm{g} \mathrm{kg}^{-1} \mathrm{~T}-2 / \mathrm{HT}-2$, respectively (Curtui et al. 2009). Taken together, these findings are in support of the notion that levels of T-2/HT-2 are elevated in the northern European countries and in the UK (Langseth and Rundberget 1999; Scudamore et al. 2007; Pettersson et al. 2008) compared to Germany in the more central area of Europe. 
Compared to the mean of all cultivars on an individual site, the cultivars Pergamon and Ivory had lower T-2/HT-2 levels for 9 and for 8 out of 10 sites, respectively (Table 3). This result suggests that these cultivars might be less sensitive to infection with Fusarium. By contrast, for the cultivars Aragon and Dominik only 6 (Aragon) or 2 (Dominik) sites had lower values than the mean. The result that Pergamon and Ivory contained decreased levels of T-2/HT-2toxins compared to the average of the cultivars appears promising with respect to the aim of lowering the levels of these toxins in foodstuff. Clearly, more research in this direction is necessary, especially as there are only a limited number of publications addressing the issue of T-2/HT-2 levels in different oat cultivars. In a study on twelve raw oat samples from the UK, Sweden and Finland Scudamore et al. (2007) found in every sample T-2/HT-2-toxins, where concentrations ranged from 143 up to approximately $3500 \mu \mathrm{g} \mathrm{kg}^{-1}$. However, they did not match their finding with different cultivars. In another study on oats in the United Kingdom, the variety Gerald cited as the most popular oat variety in the UK had the highest T-2/HT-2 concentration (Edwards 2007). In summary, the influence of the oat variety on the T-2/HT-2 level appears to be noticeable and should be further investigated.

Eight of the raw oat samples were chosen for various cleaning and food processing procedures. In the course of these experiments all analyses of T-2/HT-2-toxins were carried out using an LC-MS-method, yielding the sum of, and most advantageously, also individual levels of T-2- and HT-2-toxins. In 7 of the 8 raw oat samples HT-2 levels were higher than T2 levels, where the ratio between HT-2 and T-2 levels ranged between 2.1 and 8.7 (Table 4). Similar ratios in naturally contaminated oats were found in other surveys also involving oats from Europe (Scudamore et al. 2007).

Cleaning the raw oat material using a laboratory grain cleaner led to varying effects on levels of T-2/HT-2-toxins in the grain. Whereas a moderate reduction of toxin levels in the range of 10 to $15 \%$ was achieved for highly contaminated samples 5,6 and 8 , no reduction of toxin levels was observed for samples 4 and 7. In contrast, samples 2 and 3 showed a 100\% and 
sample 1 a $69 \%$ reduction of toxin concentrations after cleaning. The ratio between both mycotoxins in the cleaned oats was nearly the same as in the raw oats. Overall, there was no consistent effect of cleaning using the "Labofix" grain cleaner on levels of T-2/HT-2-toxins in the eight samples.

A further step in processing of oats is the de-hulling procedure. The glumes (husks) have to be separated from the oat grain before preparing e.g. oat-flakes and other products for direct human consumption. The T-2/HT-2-toxin levels of de-hulled oats are also presented in Table 4. De-hulling of oats led to a T-2/HT-2-reduction of $98 \%$ in the mean, where reduction varied between 93.8 and 100\%. These are results similar to those in oats from northern Europe (Scudamore et al. 2007) and Canada (Clear et al. 1997). The major reduction of T-2/HT-2toxins obtained by de-hulling clarify, why the consumer products from retail markets in Germany had very little T-2-/HT-2 contents although higher concentration in raw oats were found (Curtui et al. 2009). An interesting result from this work here is that after de-hulling, exclusively T-2 toxin was found at low levels in kernels, indicating that HT-2 toxin is more strictly confined to oat hulls (Table 4).

The further investigations on cooked porridge and bread were done using cleaned raw oats as starting materials for cooking and baking, because these oats had higher toxin levels than the de-hulled oat kernels. Utilisation of de-hulled kernels would very probably have resulted in T2/HT-2-toxin levels close to the limit of detection (LOD) in the final products, which has to be avoided from the analytical point of view.

The cooking of the ground cleaned raw oats with water was performed in an increasing temperature gradient of $3^{\circ} \mathrm{C}$ per min from $30^{\circ} \mathrm{C}$ to $96^{\circ} \mathrm{C}$ and a holding time of 1 min at $96^{\circ} \mathrm{C}$. In the resulting "porridge" the mean T-2/HT-2-toxin levels varied from minus 40 to plus $46 \%$ compared to the theoretical value of T-2/HT-2-toxins that would have been expected in the various samples without any T-2/HT-2-toxin alteration (Figure 3). At the present stage of experimentation we would not suggest that a significant difference between cooking treatment and T-2/HT-2-toxin level exists, because standard deviations in the cooked samples were relatively large. Analysis of matrix effects and recovery indicate that the analytical method is not the major cause of the observed variations (see Material and Methods section), leading us to conclude that the variations are due to the porridge production procedure. To our knowledge this is the first time T-2/HT-2-toxin levels were examined comparing raw and 
cooked oats. Despite the variations, the absolute T-2/HT-2-toxin levels were relatively stable during short time cooking. This is especially relevant for infant and baby food processing, as they are the consumers with a relative high consumption of cooked oats.

Observation of the T-2/HT-2-toxin levels during baking experiments was also carried out using the ground cleaned raw oats. The four highest contaminated oat meals were baked to bread in triplicate each. After baking, the resulting mean T-2/HT-2-concentration in the bread was minus $23 \%$ compared to the theoretical value of T-2/HT-2 levels without baking (Table 4). Variations ranged from plus 12 to minus $44 \%$. The significance of the result is that only a moderate reduction of toxins levels can be achieved during the baking process. One explanation is that T-2-/HT-2-toxins are relatively stable at elevated temperatures. As with preparation of porridge, the variations of the toxin levels are probably due to the bread making and baking processes, since parameters of the analytical method had no major influence (see Material and Method section). Both, preparation of porridge and bread making need to be further evaluated with respect to behaviour of T-2- and HT-2 levels under controlled conditions.

Our results illustrate that concentrations of T-2-and HT-2-toxins in oats from Germany can vary considerably, depending on variety and also location. Whereas the efficacy of cleaning was limited, de-hulling had a major reduction effect on T-2- and HT-2-toxin levels in oats. At the present stage of experimentation, results of food processing experiments indicated that cooking of porridge and bread making had little effect on T-2/HT-2-toxin levels.

\section{Acknowledgements}

The authors thank Dirk Rentel from the Federal Plant Variety Office (Bundessortenamt) for making available the oat samples and for providing information concerning the cultivation conditions of the oat varieties that are contained in internal documents not accessible to scholars. The screening work using the T-2/HT-2 antibodies was financially supported by the BMELV (Project No. 05HS001).

\section{References}

Clear RM, Patrick SK, Nowicki T, Gaba D, Edney M, Babb JC. 1997. The effect of hull removal and pearling on Fusarium species and trichothecenes in hulless barley. Can J Plant Sci. 77:161-166. 
Curtui V, Usleber E, Trebstein A, Lauber U, Hocke K, Dietrich R, Märtlbauer E, Majerus P, Zimmer M, Klaffke H, Gareis M, Betsche T, Langenkämper G. Improvement and validation of analytical methods for type A trichothecenes (T-2 toxin and HT-2 toxin) and occurrence of these mycotoxins in foods from the German market [Internet]. 2009. Bonn: Bundesanstalt für Landwirtschaft und Ernährung (BLE); [cited 2009 Oct 1]. Available from:

http://service.ble.de/fpd_ble/index2.php?detail_id=627\&site_key=145\&stichw_suche=trichot hecene\&zeilenzahl_zaehler=6

Edwards S. 2007. Investigation of Fusarium mycotoxins in UK barley and oat production, HGCA Project Report 415:1-77

Edwards S, Barrier-Guillot B, Clasen P, Hietaniemi V, Pettersson H. 2009. Emerging issues of HT-2 and T-2 toxins in European cereal production. World Mycotoxin J. 2:173-179.

Edwards SG. 2009a. Fusarium mycotoxin content of UK organic and conventional barley. Food Additives and Contaminants Part A-Chemistry Analysis Control Exposure \& Risk Assessment. 26:1185-1190.

Edwards SG. 2009b. Fusarium mycotoxin content of UK organic and conventional oats. Food Addit Contam. 26:1063-1069.

European Commission. 2006. Commission Regulation (EC) No 1881/2006 of 19 December 2006 setting maximum levels for certain contaminants in foodstuffs. Off J Eur Union. L364:5-24.

European Commission. Opinion of the Scientific Committee on Food on Fusarium toxins. Part 5: T-2 toxin, HT-2 toxin [Internet]. 2001. Bruxelles: Health and Consumer Protection Directorate-General; [cited 2009 Oct 1]. Available from: http://ec.europa.eu/food/fs/sc/scf/out88_en.pdf

Foroud NA, Eudes F. 2009. Trichothecenes in cereal grains. Int J Mol Sci. 10:147-173.

Gottschalk C, Barthel J, Engelhardt G, Bauer J, Meyer K. 2007. Occurrence of type A trichothecenes in conventionally and organically produced oats and oat products. Mol Nutr Food Res. 51:1547-1553.

Hocke KB. 2008. Entwicklung und Validierung von Enzymimmuntests zum Nachweis von T2 Toxin und HT-2 Toxin sowie Vorkommen dieser Mykotoxine in Lebensmitteln des 
deutschen Marktes [dissertation]. [München (Germany)]: Ludwig-Maximilians-Universität München. Available from: http://edoc.ub.uni-muenchen.de/8823/

JECFA (Joint FAO/WHO Expert Committee on Food Additives). Safety evaluation of certain mycotoxins in food. 2001. World Health Organization, Geneva. [cited 2009 Oct 5]. Available from: http://www.inchem.org/documents/jecfa/jecmono/v47je01.htm

Kimura M, Tokai T, Takahashi-Ando N, Ohsato S, Fujimura M. 2007. Molecular and genetic studies of fusarium trichothecene biosynthesis: pathways, genes, and evolution. Biosci Biotechnol Biochem. 71:2105-2123.

Langseth W, Rundberget T. 1999. The occurrence of HT-2 toxin and other trichothecenes in Norwegian cereals. Mycopathologia. 147:157-165.

Majerus P, Hain J, Scheer M. 2008. T-2 and HT-2 toxin analysis in cereals and cereal products following IAC cleanup and determination via GC-ECD after derivatization. Mycotoxin Res. 24:24-30.

Pettersson H, Borjesson T, Persson L, Lerenius C, Berg G, Gustafsson G. 2008. T-2 and HT-2 toxins in oats grown in Northern Europe. Cereal Res Commun. 36, Supplement 6:591-592.

Schollenberger M, Drochner W, Rüfle M, Suchy S, Terry-Jara H, Müller HM. 2005. Trichothecene toxins in different groups of conventional and organic bread of the German market. J Food Comp Anal. 18:69-78.

Schollenberger M, Müller HM, Rüfle M, Suchy S, Plank S, Drochner W. 2006. Natural occurrence of 16 Fusarium toxins in grains and feedstuffs of plant origin from Germany. Mycopathologia. 161:43-52.

Scudamore KA, Baillie H, Patel S, Edwards SG. 2007. Occurrence and fate of Fusarium mycotoxins during commercial processing of oats in the UK. Food Addit Contam. 24:13741385 .

Ueno Y. 1983. General toxicology. In: Ueno Y, editor. Trichothecenes: chemical, biological and toxicological aspects. Amsterdam (The Netherlands): Elsevier Science. p. 135-146.

Vorwerck K. 1995. Schäleigenschaften verschiedener Hafersorten. Getreide Mehl Brot. 49:10-15. 
Figure 1. Schematic diagram of the procedures and the equipments used for preparing oat based whole meal, porridge and bread.

Figure 2. Response factors for T-2- and HT-2-toxins obtained from matrix matched calibration standards. Triangles represent T-2- and rhombuses HT-2-toxin in raw oats, bread and porridge.

Figure 3. T-2/HT-2 toxins in cooked porridge samples. Porridge was prepared from five different oat samples $(n=3)$. Mean values and standard deviations as well as the theoretical content that would be expected without cooking are presented.

Figure 4. T-2/HT-2 toxins in bread. Bread was prepared from four different oat samples $(n=3)$. Mean values and standard deviations as well as the theoretical content that would be expected without baking are presented. 
Table 1. Terms and conditions of bread manufacturing process.

\begin{tabular}{lcc}
\hline \multicolumn{1}{c}{ Process parameter } & condition & \multicolumn{1}{c}{ special equipment } \\
\hline kneading & $1 \mathrm{~min}$ slow / 5 min fast & DIOSNA spiralkneader, type SP 8 \\
dough temperature & $26^{\circ} \mathrm{C}$ & \\
dough rest & $10 \mathrm{~min}$ & \\
dough per bread & dough weight $/ 2=\sim 0.8 \mathrm{~kg}$ & \\
intermediate proofing & $15 \mathrm{~min}$ & \\
forming & manuell & MANZ proofer, type G 86 W \\
final proofing & & \\
- relative humidity & $80 \%$ & \\
- temperature & $32{ }^{\circ} \mathrm{C}$ & \\
- proofing time & $35 \mathrm{~min}$ & DAUB Backmeister, type BTO \\
baking conditions & & $21613-\mathrm{S}$ \\
- steam jet & $10 \mathrm{~s}$ & \\
- baking temperature & $220^{\circ} \mathrm{C}$ & \\
- baking time & $40 \mathrm{~min}$ & \\
\hline
\end{tabular}


Table 2. MRM transitions and conditions.

\begin{tabular}{lcccccc}
\hline \multirow{2}{*}{ Analyte } & $\begin{array}{c}\text { Q1 mass } \\
{[\mathrm{amu}]}\end{array}$ & $\begin{array}{c}\text { Q3 mass } \\
{[\mathrm{amu}]}\end{array}$ & $\begin{array}{c}\text { declustering } \\
\text { potential } \\
{[\mathrm{V}]}\end{array}$ & $\begin{array}{c}\text { entrance } \\
\text { potential } \\
{[\mathrm{V}]}\end{array}$ & $\begin{array}{c}\text { collision } \\
\text { energy } \\
{[\mathrm{V}]}\end{array}$ & $\begin{array}{c}\text { cell exit } \\
\text { potential } \\
{[\mathrm{V}]}\end{array}$ \\
\hline \multirow{2}{*}{ T-2 } & 467 & 305 & 40 & 10 & 17 & 19 \\
& 467 & 245 & 45 & 10 & 17 & 19 \\
HT-2 & 425 & 263 & 50 & 10 & 12 & 15 \\
& 425 & 105 & 50 & 10 & 12 & 15 \\
\hline
\end{tabular}


Table 3. Levels of the sum of T-2/HT-2 $\left(\mu \mathrm{g} \mathrm{kg}^{-1}\right)$ in four oat cultivars from ten agricultural sites that are distributed evenly in Germany and mean levels of T-2/HT-2 $\left(\mu \mathrm{g} \mathrm{kg}^{-1}\right)$ of all four cultivars at one site. Data acquired with ELISA.

\begin{tabular}{cccccc}
\hline $\begin{array}{c}\text { Site } \\
\text { number }\end{array}$ & Aragon & Dominik & Ivory & Pergamon & $\begin{array}{c}\text { mean at one } \\
\text { site }\end{array}$ \\
\hline 1 & 67 & $40^{\mathrm{a}}$ & $33^{\mathrm{a}}$ & $36^{\mathrm{a}}$ & 44 \\
2 & $100^{\mathrm{a}, \mathrm{b}}$ & $120^{\mathrm{b}}$ & $95^{\mathrm{a}}$ & 163 & 120 \\
3 & $28^{\mathrm{a}}$ & 87 & $9^{\mathrm{a}}$ & $20^{\mathrm{a}}$ & 36 \\
4 & $42^{\mathrm{a}}$ & $42^{\mathrm{a}}$ & 129 & $28^{\mathrm{a}}$ & 94 \\
5 & 61 & 50 & $34^{\mathrm{a}}$ & $26^{\mathrm{a}}$ & 43 \\
6 & $104^{\mathrm{b}}$ & $118^{\mathrm{b}}$ & $39^{\mathrm{a}}$ & $48^{\mathrm{a}}$ & 77 \\
7 & $15^{\mathrm{a}}$ & 69 & $19^{\mathrm{a}}$ & $20^{\mathrm{a}}$ & 31 \\
8 & $26^{\mathrm{a}}$ & 54 & $27^{\mathrm{a}}$ & $31^{\mathrm{a}}$ & 34 \\
9 & $623^{\mathrm{b}}$ & $570^{\mathrm{b}}$ & $584^{\mathrm{b}}$ & $322^{\mathrm{a}, \mathrm{b}}$ & 525 \\
10 & $14^{\mathrm{a}}$ & 20 & $14^{\mathrm{a}}$ & $10^{\mathrm{a}}$ & 15 \\
\hline
\end{tabular}

Notes: ${ }^{a}$ value lower than the mean of all cultivars at the same agricultural site. ${ }^{b}$ samples chosen for further experiments involving cleaning and processing procedures. 
Table 4. Sum and individual levels of T-2- and HT-2-toxin $\left(\mu \mathrm{g} \mathrm{kg}^{-1}\right)$ in raw, cleaned and de-hulled oats and ratio of both toxins in the samples. Data acquired with LC-MS.

\begin{tabular}{|c|c|c|c|c|c|c|c|c|c|c|c|c|}
\hline \multirow[b]{2}{*}{ Sample } & \multicolumn{4}{|c|}{ raw oats } & \multicolumn{4}{|c|}{ cleaned oats } & \multicolumn{4}{|c|}{ de-hulled oats } \\
\hline & $\begin{array}{c}\operatorname{sum} \\
(\mathrm{T}-2+\mathrm{HT}-2)\end{array}$ & $\mathrm{T}-2$ & HT-2 & $\begin{array}{c}\text { ratio } \\
\text { HT-2/T-2 } \\
\end{array}$ & $\begin{array}{c}\operatorname{sum} \\
(\mathrm{T}-2+\mathrm{HT}-2)\end{array}$ & $\mathrm{T}-2$ & HT-2 & $\begin{array}{c}\text { ratio } \\
\text { HT- } 2 / \mathrm{T}-2 \\
\end{array}$ & $\begin{array}{c}\operatorname{sum} \\
(\mathrm{T}-2+\mathrm{HT}-2)\end{array}$ & $\mathrm{T}-2$ & HT-2 & $\begin{array}{c}\text { ratio } \\
\text { HT-2/T-2 } \\
\end{array}$ \\
\hline 1 & 104 & 23 & 81 & 3.5 & 36 & $*$ & 36 & - & - & $*$ & $*$ & - \\
\hline 2 & 171 & 40 & 130 & 3.3 & - & $*$ & $*$ & - & - & $*$ & $*$ & - \\
\hline 3 & 14 & 14 & $*$ & - & - & $*$ & $*$ & - & - & $*$ & $*$ & - \\
\hline 4 & 155 & 30 & 125 & 4.2 & 156 & 30 & 126 & 4.2 & - & $*$ & $*$ & - \\
\hline 5 & 670 & 214 & 456 & 2.1 & 569 & 150 & 419 & 2.8 & 13 & 13 & $*$ & - \\
\hline 6 & 845 & 87 & 758 & 8.7 & 765 & 85 & 680 & 8.0 & - & $*$ & $*$ & - \\
\hline 7 & 476 & 101 & 375 & 3.7 & 486 & 85 & 401 & 4.7 & 29 & 29 & $*$ & - \\
\hline 8 & 584 & 156 & 428 & 2.7 & 436 & 96 & 340 & 3.5 & 15 & 15 & $*$ & - \\
\hline
\end{tabular}

Notes: mean data of 3 replicates, determined with LC-MS. For T-2 the Limit of Quantification ( $\mathrm{S} / \mathrm{N} \geq 6)$ was 6 and for HT-2 the Limit of Quantification $(\mathrm{S} / \mathrm{N} \geq 6)$ was 15 . *indicates that values were below the $\mathrm{LOQ}$. 


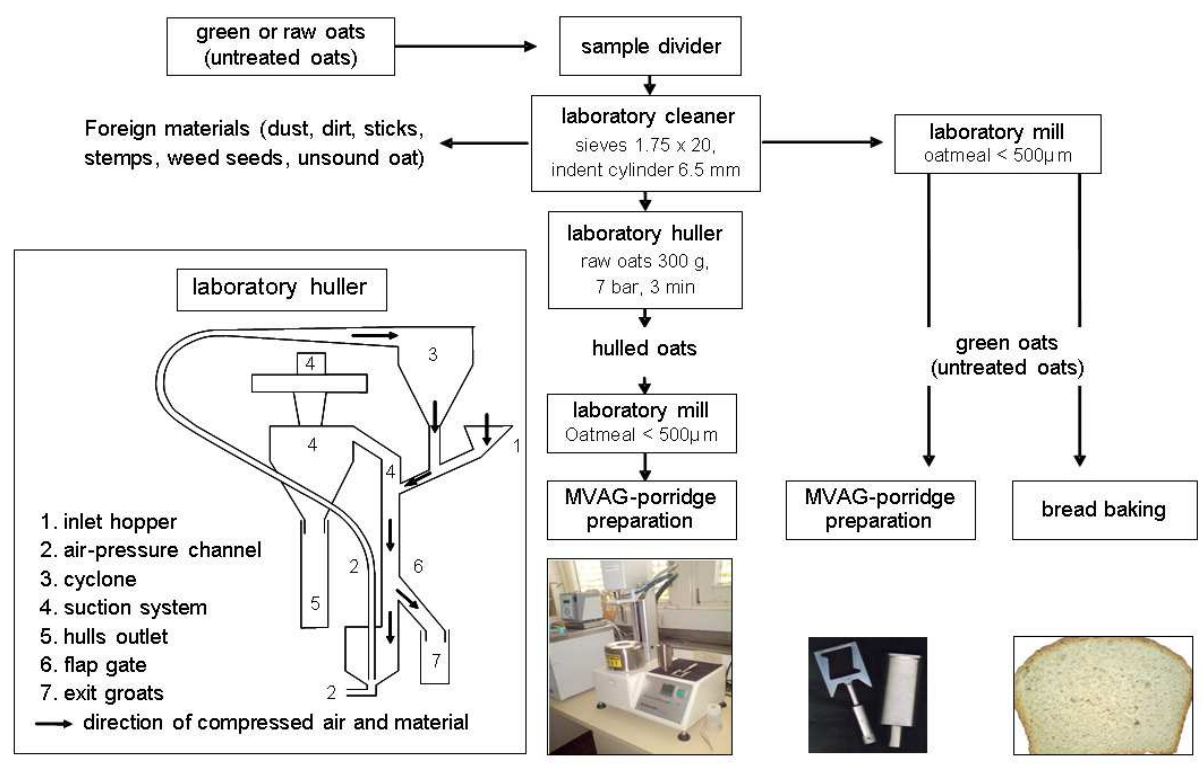

$194 \times 130 \mathrm{~mm}(150 \times 150 \mathrm{DPI})$ 


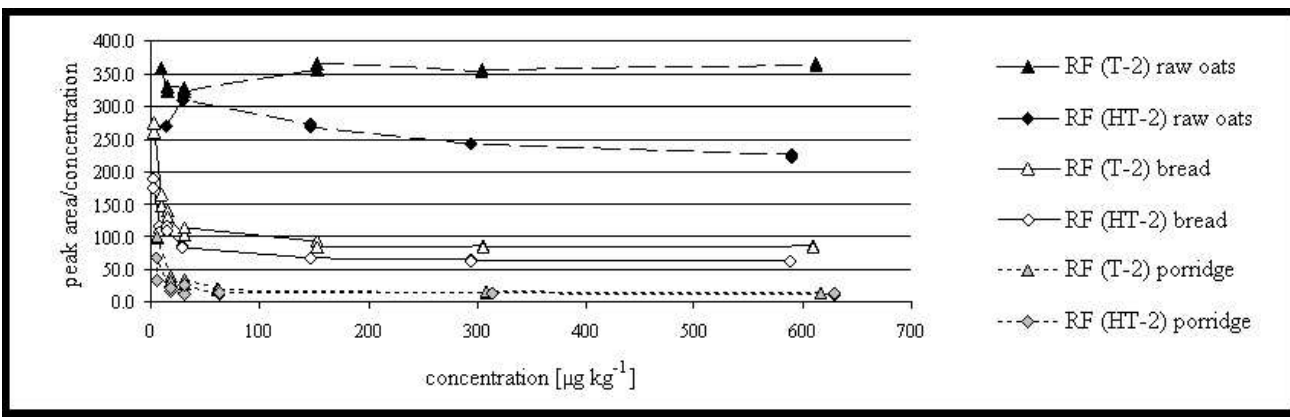

$225 \times 70 \mathrm{~mm}(96 \times 96 \mathrm{DPI})$ 


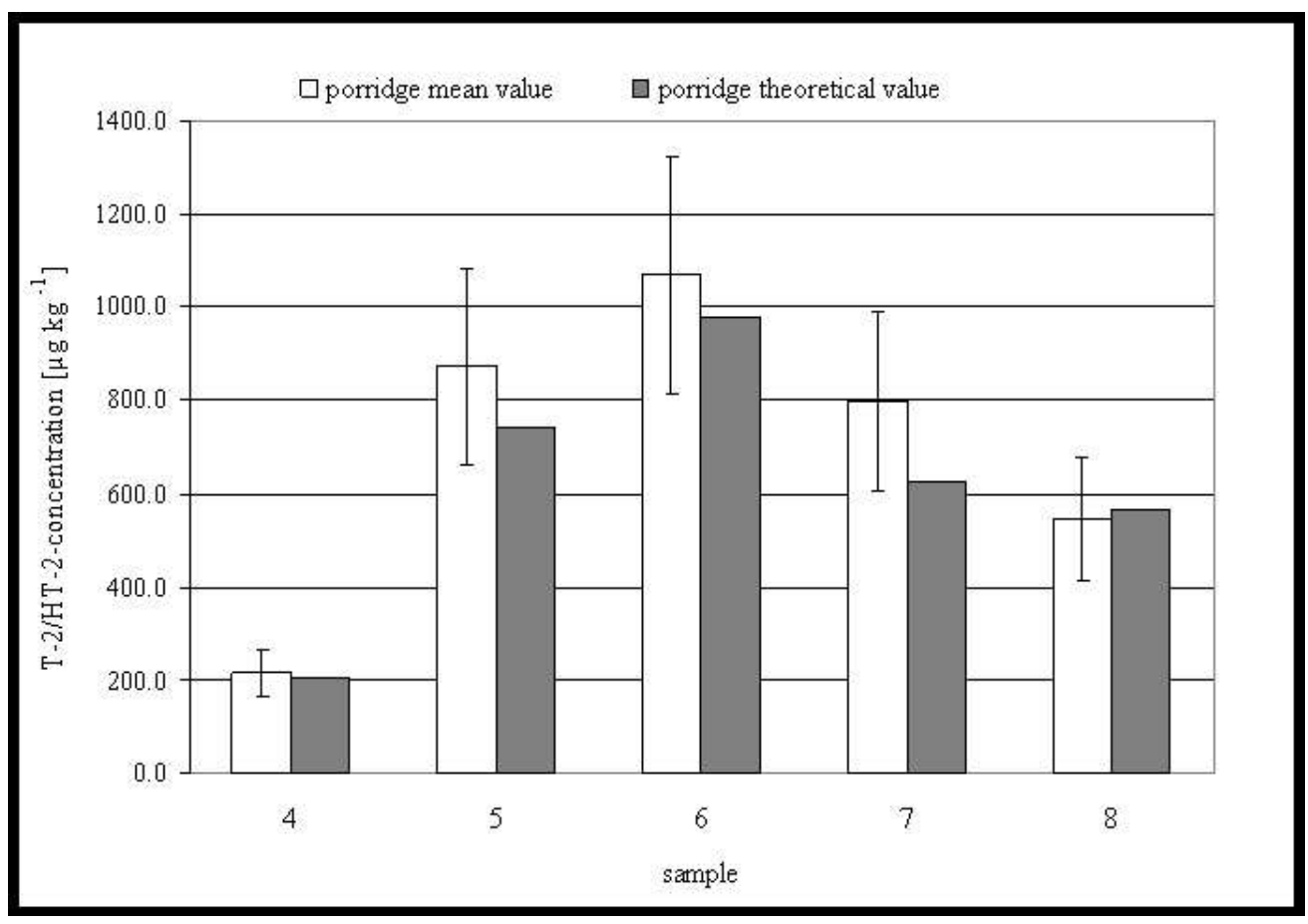

$228 \times 159 m m(77 \times 77$ DPI $)$ 


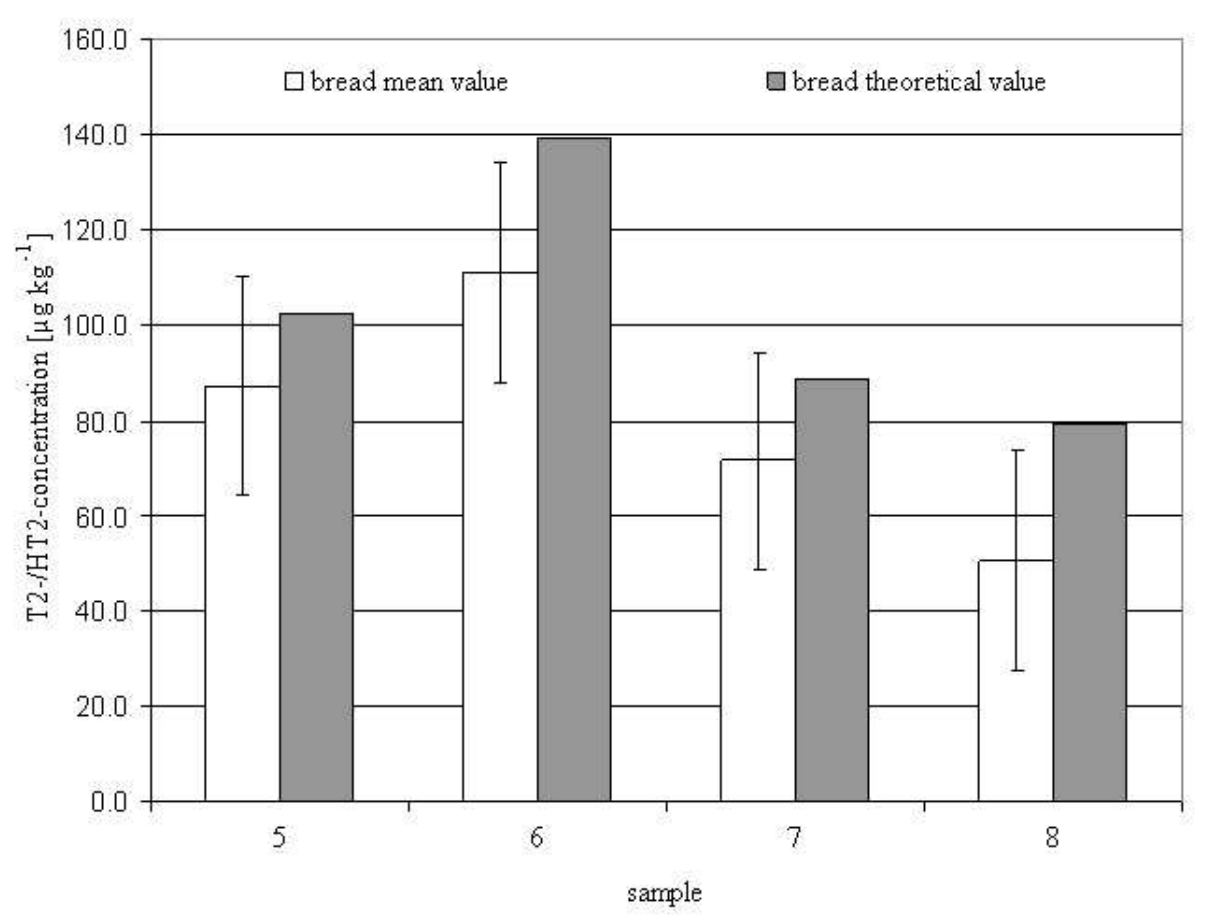

$184 \times 148 \mathrm{~mm}(96 \times 96 \mathrm{DPI})$ 